\title{
State Legitimacy and Religious Accommodation
}

\section{The Case of Sacred Places}

\author{
Janosch Prinz \\ Department of Philosophy, Maastricht University, The Netherlands \\ j.prinz@maastrichtuniversity.nl \\ Enzo Rossi \\ Department of Political Science, University of Amsterdam, The Netherlands \\ e.rossi@uva.nl
}

\begin{abstract}
In this paper, we put forward a realist account of the problem of accommodation of conflicting claims over sacred places. Our argument takes its cue from the empirical finding that modern, Western-style states necessarily mould religion into shapes that are compatible with state rule. At least in the context of modern states, there is no prepolitical morality of religious freedom that states ought to follow when adjudicating claims over sacred spaces. Liberal normative theory on religious accommodation which starts from the assumption of a pre-political morality of religious freedom is therefore of limited value. As an alternative, we suggest that the question of contested sacred places should be settled with reference to the purposes of the state, at least as long as one is committed to the existence of modern states. If one finds the treatment of religion by the state unsatisfactory, our argument provides a pro tanto reason for seeking alternative forms of political organization.
\end{abstract}

\section{Keywords}

holy places - political realism - religious accommodation - religious conflict - state legitimacy 
In this paper, we use the debate over state treatment of sacred places as a starting point for showing that any answer to normative questions of religious accommodation by states-liberal or otherwise, although we focus primarily on liberal states-must be subordinated to the question of state legitimacy, namely the question of the purposes for which the state may carry out its core activities. That is to say, there is no pre-political morality of religious freedom that the state ought to comply with, because the very idea of the political salience of religion cannot be separated from the question of state legitimacy. Consider how actor constellations differ in the state formations, for example, after the fall of the Ottoman Empire and in early modern Europe. Or think of the vastly different models of so-called state-religion relations in contemporary EU states, ranging from established churches to purported state neutrality. ${ }^{1}$ The issue of religious freedom or religious accommodation is internal to what it means for a state to be a state in its respective context.

Our argument to this effect relies on an empirical claim. We use historical and anthropological literature to show that, at least in the case of the modern (Western) state, shaping religion into a legible and governable phenomenon is essential to the proper functioning of the state. Indeed, even the accompanying notion of equal citizenship should be understood within these constraints. In a sense, this is a debunking genealogy of liberal discourse on religious freedom and freedom of conscience: the liberal illusion of a politics guided by morality causes these theorists to overlook the constraints posed by the nature of their primary tool for implementing this morality, namely the state. The guiding insight here, to quote Raymond Geuss, is that "ethics is usually dead politics: the hand of a victor in some past conflict reaching out to try to extend its grip to the present and the future." 2 The victor in the relevant past conflicts has overwhelmingly been the state.

Concretely, in the case of sacred places, we must reconcile ourselves to the fact that, as long as the modern state is our primary vehicle for the solution to political problems of non-optional coexistence, religious practices, broadly speaking, ought to be subordinated to the proper functioning of state institutions. Whether a certain road ought to be kept open on the Sabbath, then, is not a matter of figuring out whether doing so is compatible with allowing some religious citizens to act according to their conscience, or whether it hurts

1 Jocelyne Cesari, "Disciplining Religion: The Role of the State and Its Consequences on Democracy", 2 Journal of Religious and Political Practice (2016), 135.

2 Raymond Geuss, Politics and the Imagination (Princeton University Press, 2010). 
their religious feelings. Rather, it is a matter of whether the account of religious freedom that counsels closing the road as opposed to keeping it open is the optimal way of serving the purposes of the state, which in turn ought to be specified by a theory of state legitimacy, in turn constrained by a realistic understanding of the capabilities and limitations of the state as a political structure.

The upshot of our argument is an exclusive disjunction. One can either accept the subordination of religious freedom to statist priorities, or, should one find such a conclusion normatively unpalatable, one can question the suitability of the state as a social technology for solving political problems.

The argument proceeds as follows. We begin with a schematic picture of the standard way of framing the issue of state-religion relations in Anglophone liberal political philosophy. We then offer a general critique of this approach, drawing primarily on two empirically-oriented bodies of scholarship, on religion and on the state. On the basis of this general critique, in the last section we discuss the concrete question of sacred places.

\section{The Problem: the Relationship between the Liberal State and Religion}

How should the liberal state accommodate religious demands concerning the status of sacred places? The standard way to think about this questionindeed the standard way of posing it, which is prevalent in contemporary Anglophone political philosophy-is to try to work out whether granting these demands is compatible with the commitment of the state to equality for all citizens. Much of the debate rests on the question whether it is possible to grant religion a special form of protection while relying on non-religious reasons appropriate to a liberal state, ${ }^{3}$ or at the other end of the spectrum of positions, whether religious freedom even needs to be a right, or can rather be "disaggregated" across a bundle of other rights. ${ }^{4}$ One way of understanding the question of whether religion is special is to consider the status of religious

3 Compare Micah Schwartzman, "What If Religion is not Special?", 79 University of Chicago Law Review (2012), 1352, to Andrew Koppelman, "Neutrality and the Religion Analogy", 14 Northwestern Public Law Research Paper (2014) or Andrew Koppelman, "Religions as a Bundle of Legal Proxies: Response to Micah Schwartzman", 51 San Diego Law Rev. (2014), 1079.

4 Cécile Laborde, "Religion in the Law: The Disaggregation Approach", 34 Law and Philosophy (2015), 581; Cécile Laborde, Liberalism's Religion (Harvard University Press, 2018). For a synoptic view of this debate, see Leora Batnitzky \& Hanoch Dagan (eds.), Institutionalizing Rights and Religion: Competing Supremacies (Cambridge University Press, 2017). 
freedom vis-à-vis other rights. If freedom of religion is a basic liberty in liberal states, what should we do when it clashes with other basic liberties? Should, for example, blasphemy be prohibited, even against a backdrop of general freedom of speech? ${ }^{5}$ On what grounds, if any, can we say that religious freedom should have priority over other basic liberties? We will not take sides in this debate. We will, however, query one of its presuppositions, namely the idea that there is a pre-political sphere of religious belief and practice that the state ought to accommodate. To see what that means, we begin by considering this utterly simplified version of the standard liberal argument for special religious accommodation.

1. The state ought to respect religious freedom.

2. The state ought to treat all citizens equally.

3. At times, respect for religious freedom requires sacrificing other liberties.

4. Sacrificing some liberties for the sake of religious freedom does not violate the equal treatment of all citizens.

5. Therefore, at times, the state ought to sacrifice some liberties for the sake of religious freedom.

Most of the debate on whether religion is special turns on the soundness of (unpacked versions of) this argument or of its mirror version, which yields a negative conclusion. Typically, the focus is on the third and fourth premise, and the prevalent question is whether and how the special status of religion implied by these premises can be supported from a non-religious standpoint. Here, however, we focus on the first and second premises. We do not contest their truth, as this would not be tenable in a liberal context. Rather, we seek to determine from what premises they may themselves follow, to show that this way of approaching the issue misunderstands the relationship between the state and religion, not in a normative but in a descriptive sense, with respect to the constraints posed by the nature of the state.

As the schematic argument above shows, the debate is typically framed as an exercise in finding policies that are respectful both of religious practice or belief and of equality between citizens. This in turn presupposes that there is a social phenomenon - religion - whose nature is determined independently of the political agency of the state. The same is true for equality between citizens: the second premise suggests that there is a pre-politically determined notion of equality, and that the state ought to protect it or promote it.

As one would expect, there is a flourishing debate on what liberal equal citizenship is and what it entails, and on whether liberal states employ a

5 Supra note 1 and Jocelyne Cesari, "Religion and Politics: What Does God Have To Do with It?", 6 Religions (2015), 1330. 
descriptively correct account of religion. It would probably be unwise to try to offer even a cursory overview of the debate on equality. Suffice it to note that it is typically couched as a matter of first determining the sense in which citizens are equal, then working out how this equality may be brought about, through the agency of the state and by other means. What we have in mind, for instance, is the debate on "equality of what" 6 and the related one on "recognition vs. redistribution." ${ }^{7}$ To simplify, in both cases, but especially in the former, theorists try to work out what the currency of egalitarian justice is before they proceed to ask what one may do to bring it about, including through the agency of the state. This tendency is even more explicit in the more recent debate on respect and the basis of equality, ${ }^{8}$ which concerns the features of human beings on which the commitment to equal treatment is based, both in private morality and on the part of the liberal state. The standard way of grounding the second premise in the above argument is to posit that there is a pre-political and, therefore, state-independent ${ }^{9}$ notion of equality that the state ought to honour. Given the purposes of this paper, we do not discuss the origin of liberal equality.

The debate on the nature of religion and its consequences for liberalism is both more self-contained and better suited to introduce the general argument we want to put forward here. The debate starts from the contribution of scholars of religion and puts forward a critique of the standard liberal discourse of religious accommodation. The general idea is that liberal states claim to be inclusive with respect to all forms of religion, but improved descriptions of religious belief and practice show that this is not the case and that arguably that it could not even be the case. Elsewhere, one of us called this set of arguments the "descriptive challenge."10

6 Elizabeth S. Anderson, "What Is the Point of Equality?", 109 Ethics (1999), 287; G. A. Cohen, "Equality of What? On Welfare, Goods, and Capabilities", in: Martha Nussbaum \& Amartya Sen (eds.), The Quality of Life (Oxford University Press, 1993), 9; Amartya Sen, "Equality of What?", in ibid.: The Tanner Lecture on Human Values, vol. I (Cambridge University Press, 1980), 197.

$7 \quad$ Nancy Fraser \& Axel Honneth, Redistribution or Recognition? A Political-Philosophical Exchange (Verso, 2003); Axel Honneth, The Struggle for Recognition: The Moral Grammar of Social Conflicts, Cambridge (M IT Press, 1995); Iris Marion Young, Justice and the Politics of Difference (Princeton University Press, 1990).

$8 \quad$ Ian Carter, "Respect and the Basis of Equality", 121 Ethics (2011), 538.

9 The "so" in this sentence is an entailment, not a biconditional. It is not as if politics and the state are co-extensive.

10 To illustrate this challenge and critique it, we reproduce, with some modifications, parts of the argument from Enzo Rossi, "Understanding Religion, Governing Religion: A Realist Perspective”, in Cécile Laborde \& Aurélia Bardon (eds.), Religion in Liberal Political Philosophy (Oxford University Press, 2017), 55. 
The challenge makes a claim against the self-attributed inclusiveness of liberalism toward all manner of religions. A descriptively inaccurate account of religion precludes fair treatment of religion. To know what to do about religion, we need to use our best available understanding of what religion is. The liberal treatment of religion is normatively deficient because it is descriptively flawed. ${ }^{11}$ The critique assumes various forms, not all compatible with each other, but the most common descriptive critique is that liberal religious freedom is unfair to some non-Western religions because it is modelled on post-Reformation Christianity, particularly Protestantism. The idea is that Protestant religion is belief-based, whereas many non-Western religions are practice-based..$^{12}$ The view that the liberal posture toward religion is a product of the Protestant Reformation is hardly novel in historical research, ${ }^{13}$ or even in contemporary liberal theory. ${ }^{14}$ What is relatively novel in political philosophy, however, is the thought that this particular derivation of liberal religious freedom generates normative difficulties, perhaps more so once the range of religions present in liberal polities expands beyond the various branches of the Judaeo-Christian tradition. To capture this thought, a general account of the bare structure of the descriptive challenge to traditional liberal religious freedom will suffice. The challenge can be schematically presented as follows:

(1) Liberal accommodation of religion is modelled on Christianity/Protestantism (belief-and/or obligation-based, private religion).

(2) Many non-Western religions are not belief-and/or obligation-based and/ or they are not private.

(3) To be fair, religious accommodation policy must be modelled on the salient characteristics of all affected religions.

(4) Thus, liberal accommodation of religion is unfair to many non-Western religions.

In 2015, Cécile Laborde put forward a reformulation of this criticism that is more conversant with Anglophone politico-philosophical treatments of the

11 See Stanley Fish, "Mission Impossible: Setting the Just Bound between Church and State", in Stephen M. Feldman (ed.), Law \& Religion: A Critical Anthology (New York University Press, 2000), 383; Saba Mahmood, Politics of Piety: The Islamic Revival and the Feminist Subject (Princeton University Press, 2005); Jeff Spinner-Halev, "Hinduism, Christianity, and Liberal Religious Toleration", 33 Political Theory (2005), 28-57.

12 Spinner-Halev, supra note 11.

13 Guido De Ruggiero, The History of European Liberalism (Oxford University Press, 1925 [1920]); C. B. Macpherson, The Political Theory of Possessive Individualism (Oxford University Press, 1962); William T. Cavanaugh, The Myth of Religious Violence (Oxford University Press, 2009); Brad S. Gregory, The Unintended Reformation (Harvard University Press, 2012).

14 John Rawls, Political Liberalism (2nd ed., Columbia University Press, 1994). 
issue than with the praxis of liberal states: ${ }^{15}$ traditional liberal law on religious accommodation is ultimately capable of correctly capturing what is valuable in beliefs and expressive practices, but it is too narrowly focused on matters of obligation and conscience. This way of making the point begins to show what is not quite right with the standard version of the descriptive challenge, namely that it is not obvious that its descriptive claims have the advertised normative implications. This is because, as Laborde can help us see, premise (3) above is false:

The political theorists' approach is normative... It seeks to identify the core values that should be protected by the law. As a result, it eschews purely descriptive or semantic approaches to legal terms. When it considers freedom of religion, it is not concerned with defining what religion is - an elusive project at best, as critical scholars of religion have amply shown. Rather, it rejects any essentialist or semantic approach; and is concerned with identifying the core values that the law can properly express... [W] e would not want the law to capture the whole of the value of religion. At best, the law will put forward an interpretive notion of marriage, or of religion. That a particular law or theory does not capture what religion really is, therefore, is not, in itself, a sufficient objection to it. What matters is that the law, or the theory, expresses and protects the correct underlying values. It is at this more fundamental level that interpretive approaches must be assessed and evaluated. ${ }^{16}$

In other words, even if producing a satisfactory and relatively uncontroversial description of religion were possible, it would not by itself generate an account of religious freedom, suited to the purposes of liberal law. States are not academic institutions. They are not in the business of describing reality for the sake of knowledge, nor can they be, if they are to remain states. A key feature that makes states states is their way of channelling social phenomena to fit within their pre-constituted aims - chiefly the aim of securing order and stability, and achieving legitimacy in doing so. ${ }^{17}$ As shown below, this resonates

15 Laborde, supra note 4.

16 Laborde, supra note 4, 593, emphasis added.

17 Although these are generally descriptive claims, they become normative for us in the sense outlined in the first chapter of Bernard Williams's In the Beginning was the Deed (Princeton University Press, 2005), when considering the legitimacy of our respective state(s). 
both with realist approaches to political theory ${ }^{18}$ and with James C. Scott's theory of "state simplification,"19 that is, his analysis of the tendency of states to reinterpret and transform social phenomena to make them legible, and thus amenable to the particular kind of rule that comes with the state form.

For now though, let us focus on Laborde's response to the descriptive challenge:

[I]t is not enough simply to say 'religion is $\mathrm{X}$ and $\mathrm{Y}$ '. What is required is to identify the specific normative values which make $\mathrm{X}$ or Y legally relevant. Just saying that a practice or institution is multi-faceted and internally complex, and irreducible to anything else (as is surely the case with religion) does not mean that it must be recognized as such in the law... So we need to know what kind of good is being protected in every case, and the good cannot be assumed to follow from the mere description of the empirical dimension of religion. ${ }^{20}$

In this case, (3) needs to be modified:

$[\mathrm{T}]$ he claim should not be that the existing law does not protect all that is religious, according to some ordinary-meaning, semantic understanding of the term. Rather, the claim is that the law fails to protect practices which exhibit those normative values - still to be specified - which are valuable in religion. ${ }^{21}$

The salient values, then, will have to be specified "against the implicit or explicit background of a theory of fairness as inclusiveness."22

Although Laborde is right in pointing out these shortcomings of the descriptive challenge, we identify a sense in which it does not do justice to our best empirical understanding of what states are, and therefore it does not demonstrate a viable way of framing questions of religious accommodation. Our concern is that Laborde's call for determining the place of religion within the liberal state by appeal to normative considerations fails to appreciate the degree to which these considerations are intertwined with the state itself.

18 Enzo Rossi \& Matt Sleat, "Realism in Normative Political Theory", 9 Philosophy Compass (2014), 689.

19 James C. Scott, Seeing Like a State: How Certain Schemes to Improve the Human Condition Have Failed (Yale University Press, 2005).

20 Laborde, supra note 4, 595.

$21 \quad$ Ibid., 584.

22 Ibid., 583. 
Laborde's normativity is pre-political, which is not a kind suited for political theorizing. The values she seeks to specify are moral. We argue that we need to consider what about governing religions, and sacred places in particular, is most conducive to the state meeting its purposes, which in turn cannot be specified simply from one's moral wish list, but must be understood in light of a correct account of how states may or may not deal with religious phenomena. Before asking what the state ought to do, we should ask what the state is, and so what it may do, which is not merely a point about feasibility. Realists will already be sympathetic to this critique. To try and win over those who do not share this methodological perspective, we hope to be able to show empirically why pre-political normativity will not do.

Consider the empirical case for the falsity of (1). Liberal religious accommodation is not modelled on Christianity or Protestantism. By its nature, the state gets to pick out the features of reality that suit its purposes. In so doing, the state transforms the object of its rule, in the sense of "when all you have is a hammer, everything looks like a nail." Crudely, the proto-liberal state made Protestantism into what it is so that it could govern it. ${ }^{23}$ We wish to substantiate this claim by combining two sets of observations by empirical scholars from disparate fields. First, we draw on a general account of the operation of state simplification and reshaping of reality. Second, we leverage recent research on the historical origins of the liberal notion of religion and of its place in politics.

The first point has been made most eloquently by James C. Scott:

No administrative system is capable of representing any existing social community except through a heroic and greatly schematised process of abstraction and simplification. It is not simply a question of capacity... It is also a question of purpose. State agents have no interest-nor should

23 Talal Asad et al., Is Critique Secular? Blasphemy, Injury, and Free Speech (New York: Fordham University Press, 2013), ix-x, recognized how states shape religion when claiming that "secularism does not merely organize the place of religion in nation-states... but also stipulates what religion is and ought to be." Their claim that religion becomes "Protestantized" is separate from the claim that liberal religious accommodation is not modelled on Protestantism. Given that many of the people who were in favor of state centralization also felt oppressed by the pre-reformation order, it is not surprising that it would appear that the reshaping of religion by the state contains more elements of Protestantism, albeit of less radical forms. Yet, the people who were pushing for state centralization were not necessarily Protestant (e.g., Richelieu in France) (see Mark Koyama, "Ideas were not enough: Locke, Spinoza and Voltaire were all brilliant, but religious freedom in Europe was driven by statecraft not philosophy." 2017. AEON. Retrieved 18 Feb. 2020, https://aeon .co/essays/the-modern-state-not-ideas-brought-about-religious-freedom). 
they-in describing an entire social reality, any more than the scientific forester has an interest in describing the ecology of a forest in detail. Their abstractions and simplifications are disciplined by a small number of objectives, and until the nineteenth century the most prominent of these were typically taxation, political control, and conscriptions. They needed only the techniques and understandings that were adequate to these tasks. ${ }^{24}$

Scott draws on a variety of case studies-from state-sanctioned scientific forestry to land tenure schemes, from urban planning to the creation of surnames - to illustrate and substantiate this general claim. More precisely, as anticipated, there are two claims here:

These state simplifications, the basic givens of modern statecraft... did not successfully represent the actual activity of the society they depicted, nor were they intended to; they represented only that slice of it that interested the official observer. They were, moreover, not just maps. Rather, they were maps that, when allied with state power, would enable much of the reality they depicted to be remade. ${ }^{25}$

Thus, state simplifications both describe selectively and reshape by describing. Recent historical research on the place of religion in Western political discourse and practice bears this out. Again crudely, historians and theologians have shown how the category of religion is a product of the liberal or protoliberal state. ${ }^{26}$ William Cavanaugh summarised his and other historians' findings in this way:

What counts as religion and what does not in any given context is contestable and depends on who has the power and authority to define religion at any given time and place... the concept of religion... is a development of the modern liberal state; the religious-secular distinction accompanies the invention of private-public, religion-politics, and church-state

\footnotetext{
24 Scott, supra note 19, 22-23.

25 Ibid., 3.

26 This does not mean that matters of faith and worship did not play an important role in the early modern struggles, which are often called "wars of religion" and which led to Western state formation (see Barbara Diefendorf, "Were the Wars of Religion about Religion?", 15 Political Theology (2014), 552; William T. Cavanaugh, "Religious Violence as Modern Myth", 15 Political Theology (2014), 486; James Bernard Murphy, "Religious Violence: Myth or Reality? A Symposium on William T. Cavanaugh's The Myth of Religious Violence", 15 Political Theology (2014), 479.
} 
dichotomies. The religious-secular distinction also accompanies the state's monopoly over internal violence and its colonial expansion.

$[\mathrm{W}]$ hat counts as religious or secular depends on what practices are being authorized. The fact that Christianity is construed as a religion, whereas nationalism is not, helps to ensure that the Christian's public and lethal loyalty belongs to the nation-state. ${ }^{27}$

Taken in isolation, the points about state simplifications and about the particular history of the Western liberal conception of religion may seem to leave the argument untouched. But their conjunction illuminates an important point of realist flavour: the reason why Western states have historically tended to treat religion as a belief-and obligation-centric univocal practice, or rather to sculpt it into one, is that this shape is most amenable to the exercise of state power. Empirical work shows how many states that do not fit the Western mould lack the technology and power to exert this kind of influence. ${ }^{28}$ One may further posit that it is for this reason that religions from those societies do not take forms that are easily governed by Western states. One may even argue that it is the only amenable shape: the history of progressive enlargement of religious freedom coincided with an increasing standardization of the forms that the tolerated religions were supposed to take. The notion of religion at stake here crystallized just as the early-modern, sovereign state won its evolutionary struggle against other forms of political organization, from the Italian citystates to the Hanseatic League, to name just the main defeated contenders. ${ }^{29}$ Before the victory of the Western modern state over its competitors, religion was, in a sense, closer to being an alternative though coopted form of social organization rather than a subset of social practices, at least under central state government.

The point here is precisely that success in regimenting religion, in making it legible and thus governable, was one important factor in the success of the state. ${ }^{30}$ Or, conversely, the success of the state in making social practices legible

27 Cavanaugh, supra note 13, 59-6o. Also see Gregory, supra note 13.

28 Markus Daechsel, "Seeing Like an Expert, Failing Like a State? Interpreting the Fate of a Satellite Town in Early Post-Colonial Pakistan", in Marcel Maussen et al., (eds.), Colonial and Post-Colonial Governance of Islam: Continuities and Ruptures (Amsterdam University Press, 2011), 155 .

29 Hendrik Spruyt, The Sovereign State and Its Competitors (Princeton University Press, 1994).

30 As borne out by Spruyt's influential reconstruction of the rise of the modern state in Europe. 
from an administrative point of view and in expanding its enforcement capacity paved the way for moving from identity-based rules to general ones, which in turn provided support for freedom of religion, as Johnson and Koyama have argued. ${ }^{31}$ The extension of state capacity, e.g., taxation and abolition of internal tariffs, correlated with a stronger identification with the nation and with "general rules," as they show by comparing grievance books from places just inside and just outside the Cinq Grosses Fermes customs union, ${ }^{32}$ in 1788.

The best option of the state is to mould religion into a manageable shape. In this case, the most manageable shape is the belief-and obligation-centric one, given the desideratum of legal consistency and the technologies of legibility and social control made available by the rise of the modern European state. ${ }^{33}$ In a nutshell, those states made religion relatively toothless by reducing it to a single, private practice rather than a public, political contender. This sort of simplification is what the state does to make the social world legible, a condition for the effective use of its power. Any corresponding process of selection of the normative goals of states is constrained by the types of things that states are. It is not as if the state - or the theorist laying down norms for the statecan discover a correct account of what is important or morally relevant about religion, then proceed to devise policies compatible with this discovery. States must find ways to coexist with their social environment. They do so by making social phenomena legible, and in so doing they alter these phenomena. How exactly they go about it depends on the social phenomena and the actor constellation in question. ${ }^{34}$ This process is constitutive of states, at least with regard to modern, Western-style states. This is especially important for liberalism, because the modern Western state is the one form within which liberalism developed, and to which - as we know from standard Weberian analyses of the bureaucratic rationality of statecraft-it is arguably tied by more than mere historical contingency.

31 Noel D. Johnson \& Mark Koyama, Persecution \& Toleration: The Long Road to Religious Freedom (Cambridge University Press, 2019), 250.

32 A customs union initiated in 1664, which eliminated internal customs and included about half of French provinces at the time.

33 Talal Asad, Formations of the Secular: Christianity, Islam, Modernity (Stanford University Press, 2003).

34 Note here that when Western forms of statehood were later "exported" to contexts that had a more diverse religious landscape, the position that states took toward religion was not typically one of tolerance and freedom; think of the change from the relative religious freedom within the Ottoman Empire to the deterioration in the successor states (see Cesari, supra note 1). 
So far we have looked at the state-religion nexus in general. We can now restrict our focus to the issue of sacred places, in particular to contested sacred places, ${ }^{35}$ which are the most difficult cases, after which it will be possible to deal with the easier ones. ${ }^{36}$ In what way does the liberal state make the issue of contested sacred places legible? And what room for normative theorizing does answering this question leave us?

Although debates on sacred places are common, and the political-philosophical literature tends to take claims about such spaces at face value, if only because this is how such claims present themselves as political problems, there is little agreement about what should count as a sacred place. ${ }^{37}$ Deep disagreements across time and place about what constitutes a sacred place are a key factor in making conflicts over contested sacred places so seemingly intractable. ${ }^{38}$ Some scholars even question whether "sacred place" is a useful analytical category, for example, as opposed to the more accurate and less contentious, although arguably less politically expedient, "ritual space."39 This is telling, insofar as it is a way to begin to see how sacred places are not part of the fabric of the world, but rather the result of social processes of recognition. This is far too general a claim, however, and not even a particularly controversial one. What we need to consider is the form taken by that process of recognition under the hegemony of the state.

A bird's eye view of historical, anthropological, and archaeological evidence from the early states of antiquity to, more important, the modern Western state, shows a tendency toward covariation between political structures and ways of recognizing the status of sacred places. But summarizing the evidence for such a long period would be neither possible nor necessary here. What is

35 Our understanding of contested sacred places includes conflicting claims advanced by several religious groups as well as disputes about whether a place is sacred, e.g., between land developers and a religious or tribal community.

36 We remain neutral on the more abstract issue of whether contestation is a necessary feature of politics. If it is, the cases we do discuss are the only relevant ones anyhow.

37 See Thomas Coomans et al. (eds.), Loci Sacri: Understanding Sacred Places (Leuven: Leuven University Press, 2012); Alyson L. Greiner, "Sacred Space and Globalization", in Stanley D. Brunn (ed.), The Changing World Religion Map: Sacred Places, Identities, Practices and Politics (Springer, 2015), 363; for the early modern period, see Will Coster \& Andrew Spicer (eds.), Sacred Space in Early Modern Europe (Cambridge University Press, 2005).

38 For a comparison between the choreographies of the sacred in the context of the different successor states to Ottoman Empire, see Elazar Barkan \& Karen Barkey (eds.), Choreographies of Shared Sacred Sites (Columbia University Press, 2015).

Bernard Williams, Truth and Truthfulness (Princeton University Press, 2002). 
most relevant for our purposes is the relationship between the modern state and religion. In a number of influential works, Talal Asad has demonstrated how religion is not a universal category, nor a "given" that states simply must deal with. Rather, it is a "modern historical object," ${ }^{40}$ shaped by the same ideology that accompanied the rise of the modern European state:

[W]hat appears to anthropologists today to be self-evident, namely that religion is essentially a matter of symbolic meaning linked to ideas of general order... is in fact a view that has a specific Christian history... [R] eligion has come to be abstracted and universalized. In this movement we have not merely an increase in religious toleration, certainly not merely a new scientific discovery, but the mutation of a concept and a range of social practices which is itself part of a wider change in the modern landscape of power and knowledge. That change included a new kind of state, a new kind of science, a new kind of legal and moral subject. ${ }^{41}$

This general attitude translates into the more particular issue of the handling by the state of spatial conflict. To crudely simplify, the simplification strategy of the state always played a role in determining what was to count as a sacred space and what such recognition entailed. There is no such thing as a sacred space, in a politically salient sense of the term, that is not the product of state agency to a significant extent. ${ }^{42}$ One important consequence of this fact is that we cannot make epistemically reliable moral judgments as to why the state treats claims for or against granting special status to certain spaces with fairness, because the very notion of sacred space is typically itself the product of the state. ${ }^{43}$ The way that the category of religion is shaped by state simplifications may lead one to expect sacred places to have decreased in importance proportionally with the increase in state capacity, given the preferences of the state for belief-centered understanding of religion. To the extent that sacred places stand in for a rival, ritual-and practice-centered

$40 \quad$ Talal Asad, Genealogies of Religion (Johns Hopkins University Press, 1993), 4.

41 Ibid., 42-43, emphasis added.

42 Although not dissimilar, struggles for being recognized as a state and struggles for being recognized as a sacred space do not take place at the same level. The outcomes of the former have a much stronger effect on the latter than vice versa.

43 By analogy, this is as if authors were asked to referee their own papers. There are good epistemic reasons against this practice. We develop this method of realist ideology critique in Janosch Prinz \& Enzo Rossi, "Political Realism as Ideology Critique", 20 Critical Review of International Social and Political Philosophy (2017), 348; see also Enzo Rossi \& Carlo Argenton, "Property, Legitimacy, and Ideology: A Reality Check", The Journal of Politics (forthcoming, 2020). 
understanding of religion, sacred places are reminders of the still ongoing struggle between state simplification and alternative forms of social organization. That the governance of sacred spaces is one of the areas in which contemporary states have recourse to identity-based rules, the replacement of which with general rules was one of the hallmarks of the advent of the modern state form, attests to this challenge. There is a remaining tension in the manner in which the state makes sacred places legible: by seeking to make the social power of the sacred subservient to its purposes through applying state simplifications, the state still gives the concept of the sacred just enough continued social recognition for it to challenge the state form later.

Where do those broadly descriptive considerations leave us in terms of normative options to direct political agency? In their seminal paper on sacred places, Gideon Sapir and Daniel Statman classified and reviewed the most common philosophical rationales for special accommodations of claims on sacred places. We are inclined to agree with their conclusion that "the theoretical basis for the special protection granted to holy places is not entirely clear and is rather unstable," 44 therefore we do not take issue with any of their critiques of the various positions they discuss. We argue that one should be even more sceptical of standard liberal political philosophy on this issue. Sapir and Statman also noted that they found it "rather upsetting to be reminded that social and legal arrangements are often much more a result of power relations than of moral principles" ${ }^{45}$ We lack the resources to determine the extent to which reality is upsetting, but the preceding discussion helps establish two points concerning Sapir and Statman's conclusions, and more generally, what a realist approach to political philosophy would recommend regarding the choices of the state about sacred places.

First, we would like to extend Sapir and Statman's scepticism about philosophical accounts of the special status of sacred places, whether they are based on freedom of conscience, cultural rights, or other accounts of the sui generis status of religion. If our argument succeeds, it shows that it is not as if the correct way of squaring the religious freedom - equality circle has not yet been found. Rather, it cannot be found because trying to regiment state agency with pre-political moral principles is possible only if one misunderstands what sort of entities states are. For states are not as pliable to one's normative wishes as political philosophers often assume them to be, although this is not to say that

\footnotetext{
44 Gideon Sapir \& Daniel Statman, "The Protection of Holy Places", 10(1) The Law \& Ethics of Human Rights (2016), 153; see also Gideon Sapir \& Daniel Statman, State and Religion in Israel: A Philosophical-Legal Inquiry (Cambridge University Press, 2019).

Ibid., 153-154.
} 
there is a universal logic of statecraft-contextualism remains key in a realist framework. The often contradictory rationales for religious accommodation found in academic and public discourse are simply the ideological residue of different ways of negotiating the task of state simplification, to return to Scott's terminology. For instance, as some liberal states simplify through neutrality and some through laïcité, while claiming adherence to broadly similar or overlapping sets of constitutional commitments, it is not surprising that ostensible justificatory tensions emerge. All these simplification strategies are imperfect and leave a residue of cases that do not quite fit the mold.

Here one may wonder whether we have lapsed into the descriptive fallacy Laborde aptly diagnosed in parts of "critical religion" scholarship. To address this objection, we need to appreciate why our point about the state is not merely one about feasibility constraints, although it may at first sight appear so. The objection is this: the fact that states mould social practices such as religion to suit their purposes says nothing about whether they have (moral, prudential, etc.) reason to do so, unless one can also show that such state simplification is the only feasible option. But this objection fails to appreciate the import of Scott's point about state simplifications: it is not as if states chose to behave as they do; if they did not behave this way, they would not be states. The realist argument we put forward explains why states mould religious phenomena into easily governed shapes: the issue is that states need to solve what Bernard Williams called the "first political question," 46 namely the provision of legitimate order, or in Sapir and Statman's parlance, "the fear of violence and public disorder." 47 As we have seen, modern states based on the European model have quite specific ways of achieving these aims. The priority of answering the first political question still leaves many normative questions open as to how the state may best pursue that goal. How the purposes of the state are specified in a particular context is not something for political philosophers to determine; ${ }^{48}$ it should be left to the rough and tumble of politics that wins the day.

This realist approach opens a new way of thinking about the justification of religious accommodation, at least in political theory. The approach we have in

46 Williams, supra note 17.

47 The links between liberal realism and the "liberalism of fear" championed by Judith Shklar are well understood by now (see Katrina Forrester, "Judith Shklar, Bernard Williams and Political Realism", 11 European Journal of Political Theory (2012), 247).

48 At least in democracies, there should be limits to what can count as politics rather than raw domination (see Janosch Prinz \& Enzo Rossi, "Financial Power and Democratic Legitimacy: How to Think Realistically about Public Debt", Social Theory and Practice (forthcoming). 
mind is familiar to constitutional scholars, according to whom religious accommodation is a matter of balancing state priorities and the requests of religious groups ${ }^{49}$ Political theorists are typically dismissive of this approach: ${ }^{50}$ if there are obligations to respect religious commitments, balancing will not do. But here we have shown that this type of moralistic reasoning requires, among others, the false premise that religion is independent of the state and therefore must be treated fairly by it. The realist lesson is that there is no pre-political morality of religious freedom. Thus, in a way, the realist approach we propose can afford a vindication of the relatively hard-nosed, gritty reasoning found in constitutional theory and practice.

We argue for an approach according to which the recognition and regulation of sacred sites depends on the judgment of the state of what would minimize the chance of failing to provide a legitimate order. This is not to say, however, that might makes right. As Bernard Williams argued, ${ }^{51}$ and as much realist literature has shown, the establishment of order does not count as a proper political relationship, as opposed to suspended warfare, if the order does not in some way make sense to those subjected to it..$^{52}$

Such an approach would not involve compromise between "state" and "religion." In our account, governing contested sacred places should be guided by prudential reasoning by states about the effect on the legitimacy of the political order, rather than by trying to determine which religion has the most

49 Christopher L. Eisgruber \& Lawrence G. Sager, Religious Freedom and the Constitution (Harvard University Press, 2007).

5o Yuval Jobani \& Nashon Perez, "Governing the Sacred: A Critical Typology of Models of Political Toleration in Contested Sacred Sites", 7 Oxford Journal of Law and Religion (2018), 250 , capture the hard nature of these choices in their insightful outline of the advantages and disadvantages of a range of approaches to the governance of contested sacred sites. They do not consider, however, how the state has shaped the category of religion, and hence their outline is of limited use for our purposes.

$5^{1} \quad$ Supra note 17.

52 Emmanuela Ceva \& Enzo Rossi (eds.), Justice, Legitimacy, and Diversity: Political Authority Between Realism and Moralism (Routledge, 2013); Matt Sleat, "Legitimacy in Realist Thought: Between Moralism and Realpolitik", 43 Political Theory (2014), 314. This is not a moral commitment but a point following from a conceptual claim about the distinction between politics and war (Hall, 2015). On the normative status of this claim there is an ongoing debate (see, e.g., Eva Erman \& Niklas Möller, "Why Political Realists Should Not be Afraid of Moral Values", 40 Journal of Philosophical Research (2015), 459; Robert Jubb \& Enzo Rossi, "Political Norms and Moral Values", 40 Journal of Philosophical Research (2015), 455; Robert Jubb \& Enzo Rossi, "Why Moralists Should Be Afraid of Political Values: A Rejoinder", 40 Journal of Philosophical Research (2015), 465; Janosch Prinz, "Principles, practices and disciplinary power struggles in political theory", European Journal of Political Theory (2019). 
objective claims to "holiness" or "sacredness" of a place. ${ }^{53}$ Compromise between state and religion could not play a central role, because the religious claims, according to our arguments above, are not-now and around herestate-independent artefacts. Such an approach would divide conflicts over contested sacred spaces into two main but not neatly separated categories and recommend responses accordingly.

On one hand, there is conflict over contested sacred places as power struggle over social and political control (of the purposes) of the state; for example, which religion, if any, the state favours. If conflicts over the governance of sacred places boil down to such power struggles, special status would distract from what these conflicts are about. ${ }^{54}$ To the extent that claims regarding sacred places are instrumental to gaining control of state power, without seeking to transform the state form, no special governance provisions would seem necessary in our approach, although there may be borderline cases. ${ }^{55}$ An example of this could be the dispute in the early 1980 over the then newly funded settlement of Rajneeshpuram in Oregon: a minority religious group started settling an area adjacent to an existing city (Antelope), and subsequently obtained incorporation as a new city whose local government, including education and security, it completely controlled. ${ }^{56}$ The ensuing successful legal challenge by the Oregon State Attorney was ostensibly centred on the Establishment Clause of the US Constitution. Our political realist reading, however, is in line with what jurisprudence scholars of the American legal realist school would say: judicial decisions of this kind are always determined by extra-legal factors: moral and political convictions, interests, etc. ${ }^{57}$ In particular, we think that a

53 One may reasonably worry that such an approach is liable to give some groups a threat incentive: Are groups more likely to have their demands met the more they menace public order? To avoid a straightforward affirmative answer, it seems that those in charge will have to make complex cost-benefit calculations. It is not in the spirit of realist political theory to provide detailed blueprints or algorithms for how those calculations should be conducted (see Enzo Rossi, "Being Realistic and Demanding the Impossible", Constellations (2019)).

54 There are important differences if one of the groups involved has been discriminated against or is at the weaker end of a historical power differential relating to state capture. As we have suggested above, in liberal democracies there should be limits to how far the rough and tumble of politics may cater to the interests of a very limited segment of the population. We cannot, however, do justice to this topic here.

55 Our schema does not, however, cover international conflicts over sacred places.

56 James T. Richardson, Regulating Religion: Case Studies from Around the Globe (Springer, 2003).

57 Brian Leiter, "Legal Formalism and Legal Realism: What is at Issue?", 16 Legal Theory (2010). 
realist approach counsels giving priority to extra-legal considerations pertaining to the successful answering of the first political question.

On the other hand, there is conflict over contested sacred places that involves a challenge to the state as the main form of social organization. Here the task of the state would be to show arguments for why it provides a superior form of social organization for all considered. Such a challenge comes to the fore when the understanding of the sacred presented in the contestation is incompatible not only with the particular policies of the state, but with state simplification of religion altogether, for example, because they cannot capture the sacredness at issue. Consider the recent protests over the Dakota Access pipeline. The Native American Standing Rock Sioux Nation claims that the construction of the pipeline would disturb their sacred land. Existing legislation for the protection of freedom of religion, however, has not served Native American religions, despite the "American Indian Religious Freedom Restoration Act" of 1978. Arguably, because of the divergence of their land-based understanding of religion from state simplified religion, Native American groups' understanding of the sacred is not protected within the US state. ${ }^{58}$ If conflict over sacred space involves a claim to self-determination or sovereignty, it is a direct challenge to the state order. ${ }^{59}$ If conflict over contested Native American sacred land is a case of mobilizing interpretations of a concept (the sacred), which are less compatible with the current form of the state than the established interpretations, in order to change the state from within, then it is a hybrid between the first and second category. The example is further complicated by the fact that a group that was forcibly integrated into the state society can achieve recognition for its claims only through the organs of that state, the same one that disregarded its prior claims to self-governance. Dealing with such challenges is less a question of adjudicating between competing claims than one of finding out whether state-based politics can satisfactorily incorporate the claims of groups that have historically been marginalized, in many ways precisely through state simplification and other, even more brutal forms of state-building.

Building on that last point, we note that we are left with an exclusive disjunction, which may or may not exhaust the available options, but the two we mention strike us as the most appealing ones, and we do not try to adjudicate between them. On one hand, one may embrace the hard-nosed priority of the

$5^{8}$ Tisa Wenger, Religious Freedom: The Contested History of an American Ideal (University of North Carolina Press, 2017).

59 Tisa Wenger. “Why Religious Freedom Won't Protect Native American Sacred Lands”. 2018. Berkley Center. Retrieved 18 Feb. 2020, https://berkleycenter.georgetown.edu/responses/ why-religious-freedom-won-t-protect-native-american-sacred-lands. 
first political question; on the other, even if one is reconciled to abandoning the moralist search for pre-political moral principles for guiding state agency, one may still be disappointed with the limitations imposed by the ontology of states. ${ }^{60}$ Thus, the issue of sacred places may become a gateway to the radical conclusion that the very existence of states is normatively problematic: perhaps there are commitments and social practices (such as religion, whatever that may be) which we have reason to value more than we value the goods provided by states. ${ }^{61}$

That is not to say that if one is unhappy with statism one can retreat into moralistic pre-political commitments. One must still reckon with the need for political institutions, at least as long as humans have no choice but to coexist in non-optional associations, as seems to be inevitable for creatures such as ourselves. ${ }^{62}$ This is one more reason why prospects for a pre-political morality of religious freedom seem dim. The question for radically minded realists, then, is whether there are non-state frameworks and institutions that can enact more satisfactory ways of making sense of the politics of religion.

\section{Acknowledgments}

This paper was presented at the Conference on Sacred Places at Bar-Ilan University. We are grateful for the insightful comments of the audience. Special thanks go to Karen Barkey, Jocelyn Cesari, Ruth Gavison, Nahshon Perez, Gideon Sapir, Danny Statman, and Jonathan Seglow. Enzo Rossi's research for this essay was supported by the Dutch National Science Organisation's (NWO) Vidi project "Legitimacy Beyond Consent" (grant n. 016.164.351). Janosch Prinz would like to thank the Leverhulme Trust for supporting his research with an Early Career Fellowship (ECF-2016-227).

6o On the compatibility between realism and anti-statism, see Paul Raekstad, "Realism, Utopianism, and Radical Values", 26 European Journal of Philosophy (2018), 145.

61 Yet, if the state has shaped the category of religion, then making such a choice against the state order may be practically difficult because it would require first unearthing some alternative form of religion unaffected by state influence. After centuries of state rule, such a form of religion may be difficult to unearth.

62 In forthcoming work, Enzo Rossi defends a form of realist political naturalism that substantiates this claim. 